\title{
The establishment of exotic Chinook salmon (Oncorhynchus tshawytscha) in Pacific rivers of Chubut, Patagonia, Argentina
}

\author{
C.Y. Di Prinzio ${ }^{1,2 *}$, M.A. Pascual ${ }^{2,3,4}$ \\ ${ }^{1}$ Laboratorio de Investigación en Ecología y Sistemática Animal (LIESA), Universidad Nacional de la Patagonia, Ruta 259 km 5, (9200) \\ Esquel, Chubut, Argentina \\ ${ }^{2}$ Consejo Nacional de Investigaciones Científicas y Técnicas (CONICET), Av. Rivadavia 1917, (1033) Buenos Aires, Argentina; \\ ${ }^{3}$ Centro Nacional Patagónico CENPAT (9120) Puerto Madryn, Chubut, Argentina \\ ${ }^{4}$ Universidad Nacional de la Patagonia SJB, Argentina
}

The aim of this paper is to report the colonization process of three headwater rivers of two large trans-national Pacific river basins shared by Chile and Argentina, by exotic Chinook salmon (Oncorhynchus tshawytscha). To characterize the populations at the sites, fish were analyzed in terms of length, weight, age, and stream residency patterns. Fishermen familiar with the area were interviewed to establish the seasonal occurrence of fish and to reconstruct the history of the colonization process. Records of salmon production in Chile by regions were examined to evaluate the potential origin of fish in coastal net pen aquaculture. The regularity of spawning runs in our study sites indicates that Chinook salmon have established spawning populations in these rivers. While spawning was verified in all three rivers, only one seems to serve as a holding area for pre-spawning salmon early in spring. The correlation in the historical occurrence of Chinook salmon in the three rivers suggests that they have been colonized as part of the same introduction event. Moreover, the temporal correlation with the development of ocean net pen production for this species in the Chiloé region suggests that the fish may originate from escapes from these enterprises. As in all previous reports of exotic Chinook salmon in Patagonia and New Zealand, populations in the three rivers have a combination of stream and ocean ecotypes. We discuss the importance of plasticity in critical life history characteristics for the success of Chinook salmon in Patagonia, compared to other species of anadromous salmonids.

Keywords: Invasion, Chinook salmon, Pacific basins of Argentina, Patagonia.

\section{Introduction}

Salmon and trout species, which are native to the northern hemisphere, are among some of the most widely introduced species around the world, including southern South America. Over the last 20 years, Chile has become a colossal producer of farmed salmon (FAO 2002). With an annual production of over half a million metric tons (SERNAP 2005), it is expected to soon surpass Norway as the largest producer in the world (SalmonChile 2005). The beginnings of salmon aquaculture in Chile can be traced back to different ocean ranching experiments conducted during the early 1980 (Basulto 2003). Although these experiments failed to produce significant results from a commercial viewpoint, they developed knowledge and methods that launched ocean net pen aquaculture. The ideal conditions provided by the Chilean coast for temperate water aquaculture quickly attracted over-

\footnotetext{
* Corresponding author : E- mail: cdiprinzio@liesa.org.ar
}

seas investments and technology, producing highly productive salmon aquaculture that continues to grow.

As salmon aquaculture increased, so did reports of fish straying into rivers of southern Chile (Soto et al. 2001) and Argentina (Grosman 1992, Ciancio et al. 2005, Becker et al. 2007, Pascual \& Ciancio 2007). Because of the complexity of the salmon life cycle, their introgression can have cascading effects on both marine and freshwater communities (Pascual \& Ciancio 2007). Anadromous salmon may constitute an important agent for the transport of nutrients from the ocean to freshwater and thus disturbing natural cycles and balances of the system. Other potential problems are introduction of new diseases and disruption of the community due to predation and competition. So, evaluating risks associated to their expansion presents us with a huge challenge. A logical first step is to track the presence of spawning populations of a particular species, which constitute the basic demographic unit of salmon metapopulations (Cooper \& Mangel 1999). 
Of all species used by the Chilean aquaculture industry, Chinook (Oncorhynchus tshawytscha) salmon has been the most successful at invading river basins and establishing populations, although this species makes up a small fraction (less than 5\%) of all Chilean salmon production (Pascual \& Ciancio 2007). At present, Chinook salmon distributes from the Tolten river in Chile $\left(39^{\circ} 05^{\prime} \mathrm{S}\right.$ lat), all the way south to rivers in the Magallanes region of Chile (Correa \& Gross 2007; Soto et al. 2007), and around Cape Horn and into the Santa Cruz river of Argentina, an Atlantic river basin (Ciancio et al. 2005).

This paper describes the colonization process in the headwaters of three Pacific rivers of Patagonia by Chinook salmon in the north of its present distribution. Specifically, our aims were a) to analyze the incidence of this species over space and time, b) to describe some general biological characteristics of these populations, and c) to relate the progress of the invasion with that of salmon aquaculture in Chile.

\section{Study area}

This study was conducted in an area of the Andes in northwestern Patagonia, between 43 and $45^{\circ} \mathrm{S}$, and west of $71^{\circ} \mathrm{W}$. A cold temperature forest dominated by Nothofagus and the perennial Austrocedrus chilensis covers most of the catchments (Veblen et al. 1996), which extends over a strong rain gradient characteristic of the east side of the Andes (Paruelo et al. 1998). Precipitation in this region is as high as $3000 \mathrm{~mm} \mathrm{y}^{-1}$, while that in the specific sites reported in this study varies between 500 and $900 \mathrm{~mm}$ (Table 1).

Table 1. Physical features, morphometric parameters and mean values of hydrological variables in three rivers in the Patagonian Andes basin, Argentina.

\begin{tabular}{|c|c|c|c|}
\hline & Futaleufú river & Corcovado river & Pico river \\
\hline \multicolumn{4}{|l|}{ Catchments descriptors } \\
\hline Latitude & $43^{\circ} 08^{\prime} \mathrm{S}$ & $43^{\circ} 33^{\prime} \mathrm{S}$ & $44^{\circ} 20^{\prime} \mathrm{S}$ \\
\hline Longitude & $71^{\circ} 35^{\prime} \mathrm{W}$ & $71^{\circ} 29^{\prime} \mathrm{W}$ & $71^{\circ} 32^{\prime} \mathrm{W}$ \\
\hline Altitude (m.a.s.l.) & 320 & 429 & 525 \\
\hline Stream order ${ }^{1}$ & 6 & 4 & 4 \\
\hline Mean Annual Air Temperature ${ }^{2}{ }^{\circ} \mathrm{C}$ & 11,4 & 11,3 & 10,8 \\
\hline Discharge ${ }^{3}\left(\mathrm{~m}^{3} / \mathrm{s}\right) *$ & 46.25 & 263.3 & 29.36 \\
\hline Observation section $(\mathrm{km})$ & 22 & 53 & 23.5 \\
\hline Rainfall $^{4}(\mathrm{~mm} / \mathrm{y})$ & 743 & 905 & 560 \\
\hline Substratum type composition $* *$ & Gravel/Sand & Gravel/Boulder/Sand & Gravel/Sand \\
\hline
\end{tabular}

Three rivers, which are headwaters of two large trans-national Pacific river basins shared by Chile and Argentina, were considered in the analyses. River selection was based on reports from local anglers of the presence of salmon, plus some distinctive features of the watercourses such as accessibility. The Futaleufú, the largest of the three rivers (Table 1), constitutes the main tributary of the Yelcho river basin. Our observations for this river correspond to the $22 \mathrm{~km}$ section in Argentina from the limit with Chile up to the Futaleufú Dam (built during 1970) that acts as an effective barrier for salmon movement upstream. The Corcovado and the Pico rivers constitute the two main tributaries of the Palena River
Basin (Fig. 1). The Corcovado river is a $4^{\text {th }}$ order stream, with a large head lake, Lago Vintter. Our observations for this river correspond to the $53 \mathrm{~km}$ section in Argentina from the limit with Chile up to the locality known as Poncho Moro. The Pico, the smallest of the three rivers, is a $4^{\text {th }}$ order stream. Our observations for this river correspond to the $23.5 \mathrm{~km}$ section in Argentina from the limit with Chile up to the locality known as Paso Knollseisen. Both the Yelcho and Palena river basins drain their waters into the Gulf of Corcovado in Chile. Albeit their differences in size and other physical characteristics (Table 1), the three rivers have a water regime dominated by heavy rains in winter and snowmelt during spring. 


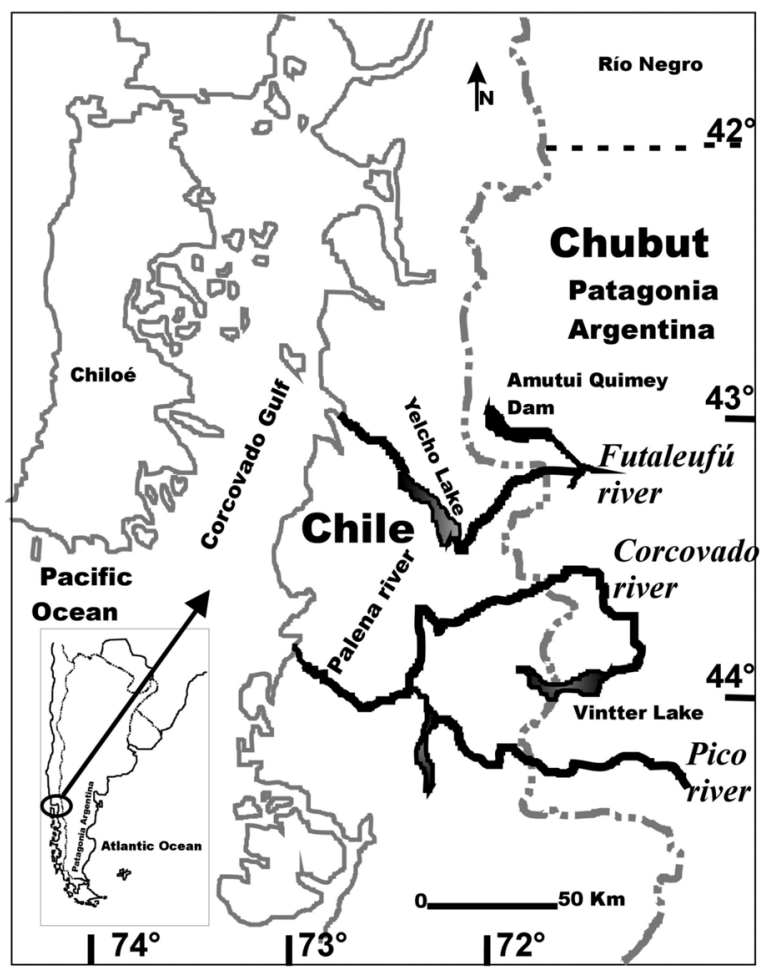

Fig. 1. Study area showing drainage basins (thick lines) in three rivers, headwaters of two large trans-national Pacific river basins shared by Chile and Argentina: Futaleufú river, Corcovado river and Pico river.

\section{Materials and methods}

\section{Fish data collection}

Data collection was conducted from different sources between 1999 and 2001, during the fishing season (September-May). Surveys of sport anglers were conducted to record information about the presence of the species in each of the three rivers basins. We interviewed a total of 60 fishermen that were familiar with the area, who had expressed an interest in the presence of salmon, and many of whom had documented salmon captures with photographs. Additional information collected during surveys consisted of the seasonal presence and abundance of the species in each of the three river reaches considered.

We recruited a selected group of anglers (ten) of recognized experience in sport fishing to report their catches to us and, whenever possible, to let us measure and collect biological samples from captured fish. In the Pico river, where sport fishing for salmon is less important, we set multifilament gillnets (3,5" between knots) across the river for five hours in May 2000. In order to verify spawning activity, identify the spawning and holding areas and to validate the information provided by the interviewees, periods of seining (at least 80 hours per river) were made throughout the study in the three rivers.

\section{Life history characteristics}

We measured fork and standard length, weighed and sexed the fish, took tissue samples for posterior DNA analyses, and collected scales and otoliths for ecotype and age determination. We removed scales from both sides of the fish, from an area located below the anterior margin of the dorsal fin, approximately five scale rows above the lateral line. Three scales of each of the fish collected were cleaned, impressed on acetate cards and inspected on a microfiche reader.

A large part of the variation in Chinook life history is associated with the existence of two behavioral forms in this species (Healy 1991). Stream-type Chinook spend one or more years as fry or parr in freshwater before migrating to the sea. Ocean-type Chinook migrate to sea during their first year of life. Freshwater residence pattern often co-varies with the timing of adult return to freshwater. Populations that produce stream-type juveniles tend to have adults returning earlier in the year than ocean-type populations (Healy 1991). Therefore, determining behavioral types provides important clues about river use by both juveniles and adults and, hence, about time windows for the interaction with the receiving river and ocean communities.

We classified individual fish as "stream" or "ocean" type based on criteria for the pattern of circuli in the freshwater nucleus developed by Koo \& Isarankura (1967) for North American chinook salmon, applied by Unwin \& Lucas (1993) to the species in New Zealand, and by Ciancio et al. (2005) to chinook in the Santa Cruz River. The abrupt change from narrowly spaced circuli near the scale focus or center to wider spaced circuli formed during growth in the ocean were used as a signal to separate the freshwater nucleus from marine growth zones. We considered a freshwater growth zone with few and relatively wide circuli that did not contain a slow-growth check as an ocean-type freshwaternucleus, and an area of many circuli including a distinct narrow band of more closely spaced circuli near the outer border as a stream type freshwater nucleus. As a supporting criterion for our ocean/stream distinction, we counted circuli within the freshwater growth zone, expecting scales of stream type fish to have significantly more circuli than those of ocean type fish. While ocean annuli were clearly identifiable, 
scale margin resorption was very strong and we did not intend to estimate ocean age.

The weight to length relationship for fish collected from different rivers was described with linear regression models $\left(\right.$ Weight $=$ slope + intercept ${ }^{*}$ Length $)$. We only had weight data for three individual from the Pico River, so only Futaleufú and Corcovado Rivers were considered in this analysis (9 and 35 fish respectively). Four possible alternative models were fitted to the data:

1) Reduced model: equal slope and equal intercept in Futaleufú and Corcovado

2) Full model: different slope and different intercept

3) Homogeneus slope: equal slope and different intercept

4) Homogeneous intercept: different slope and equal intercept

The homogeneity in slope and intercept between rivers was tested by means of sequential likelihood ratio tests of models of different complexity, assuming normality (Hilborn \& Mangel 1997). Additionally, an Akaike Information Criterion (AIC) was used to compare the fit of the four models (op.cit.)

\section{Colonization and potential origins}

To record historical occurrences of Chinook salmon, we interviewed 60 people ( 20 per river) including sport fishers, local residents, fishing guides, and fishing guards. We asked them for the year they first saw a Chinook salmon in that particular river, a description of the seasonal occurrence of fish (month of arrival to the river sections considered), their opinion about trends in numbers, the particular locations in the rivers where they consistently saw or caught fish, and a description of the fish (color and shape as indicative of maturation status). To characterize the potential sources of fish colonizing river basins, we analyzed records on total salmon production and Chinook salmon production in Chile by regions and by year (SERNAP 2005). Pearson's correlation was employed to assess the relationship between the production of Chinook salmon in Chile and the presence of individuals of this species in the Corcovado river as reported in the interviews (Sokal \& Rohlf 1995).

\section{Results}

A total of 50 Chinook salmon were collected for this study. We collected 35 salmon from Corcovado river (18 males and 17 females), nine from Futaleufú river (seven males and four females) and six from Pico river (four males, weight recorded for only three fish). The mean length of the Chinook salmon caught were $87.65 \mathrm{~cm}$ (range 53-120, sd 15.46), $94.75 \mathrm{~cm}$ (range 88-100, sd 5.08), and $94.3 \mathrm{~cm}$ (range 84-111, sd 12.92) in the Corcovado, Futaleufú and Pico rivers respectively. The mean weight of salmon specimens were $10.13 \mathrm{~kg}$ (range 1.7 18, sd 4.31), $8.42 \mathrm{~kg}$ (range 6.0-12, sd 2.26), and $9.6 \mathrm{~kg}$ (range 5.8-17, sd 6.35) in the Corcovado, Futaleufú and Pico rivers respectively.

The weight at length of fish from the Corcovado River is apparently higher than that of fish from the other river (Fig. 2). A significant difference in length-weight relationships between the Corcovado and Futaleufú rivers supports this observation (Table 2). Model selection based both on likelihood ratio tests and on AIC indicates that the data of these two rivers is best depicted by a model with homogeneous slope and a lower intercept for Futaleufú River fish, consistent with higher weight of Corcovado River fish for equivalent lengths.

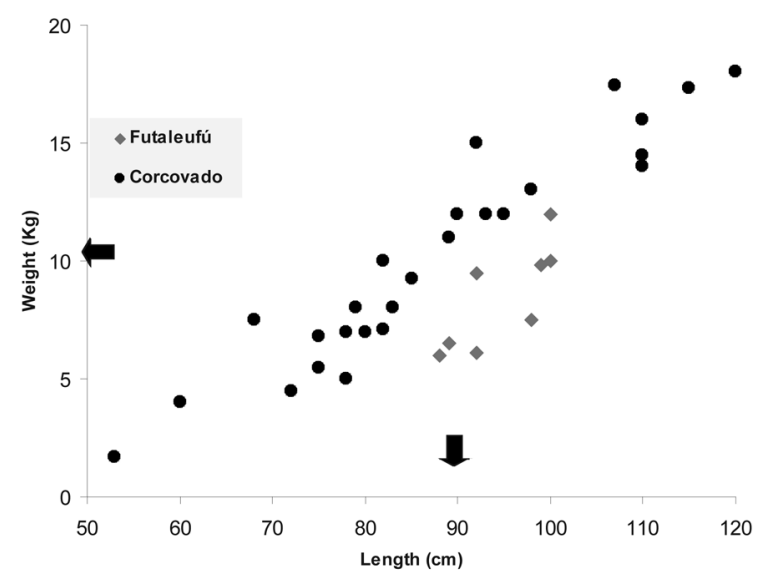

Fig. 2. A significant difference in length-weight relationships between the Corcovado and Futaleufú rivers observed during the survey (1999-2001).

Pearson's correlation between the total annual sightings in the Corcovado river and the annual Chinook salmon production in Chile was significant $(\mathrm{r}=0.65 ; \mathrm{p}<$ $0.05 ; \mathrm{N}=15)($ Fig. 3 ) showing that in years with a higher annual Chinook production, more Chinook were observed.

\section{Occurrences over space and time}

Seining and the appearance of carcasses indicate that spawning activity takes place in all three rivers. Interviews indicate that, in Argentinean sections of rivers, Chinook salmon historic occurrence are at least since 1986 and 1987 in Corcovado and Futaleufú river respectively and later in Pico river (1990) (Fig.4 a). Also, indi- 
Table 2. Model selection for the linear length-weight relationship for fish from the Corcovado and Futaleufú rivers based on likelihood ratio test (LRT) and Akaike Information Criterion (AIC). Methods sensu Hilborn \& Mangel (1997).

\begin{tabular}{lcccccc}
\hline \multicolumn{1}{c}{ Model } & Parameters & SSQ & -2 LRT & $\begin{array}{c}\text { Model } \\
\text { tested }\end{array}$ & p-value & AIC \\
\hline 1. Full & 4 & 75.59 & & & & 31.81 \\
2. Reduced & 2 & 173.49 & 36.55 & 2 vs 1 & $<0.0001^{* *}$ & 64.36 \\
3. Homogeneous slope & 3 & 77.46 & 1.07 & 3 vs 1 & 0.30 & 30.89 \\
4. Homogeneous intercept & 3 & 79.31 & 2.11 & 4 vs 1 & 0.15 & 31.92 \\
\hline
\end{tabular}

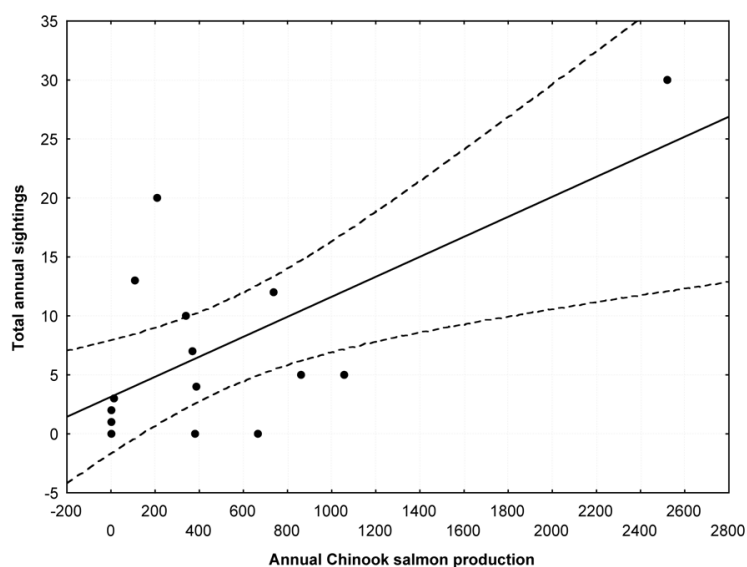

Fig. 3. The Pearson's correlation of the annual Chinook salmon production in Chile and the total annual sightings in Corcovado river. Total annual sightings $=3.1377+0.00848 *$ Annual Chinook salmon production, Correlation: $r=0.65035,95 \%$ confidence.

cate that Chinook salmon seasonal presence is first seen in the Corcovado river (early spring), a little later in the Pico river, and last in the Futaleufú river, during mid Summer (Fig. 4 b). Consequently, a significant recreational fishery for Chinook salmon has developed in the Corcovado river, where fish can be caught in good condition in resting areas, well before spawning in the Fall. Both the smallest $(53 \mathrm{~cm} ; 1.7 \mathrm{~kg})$ and largest fish $(120 \mathrm{~cm}$; $18 \mathrm{~kg}$ ) recorded were caught in this river. Meanwhile, the Argentinean sections of the Futaleufú and Pico rivers appear to be primarily spawning areas, with resting areas presumably occurring in downstream locations in Chile. The differences detected in length-weight relationships for the three rivers are consistent with this scenario.

\section{Stream residency}

We found two contrasting patterns in scale freshwater nuclei, consistent with different stream residency patterns: one with few closely spaced circuli corresponding to freshwater growth, which we identified with short
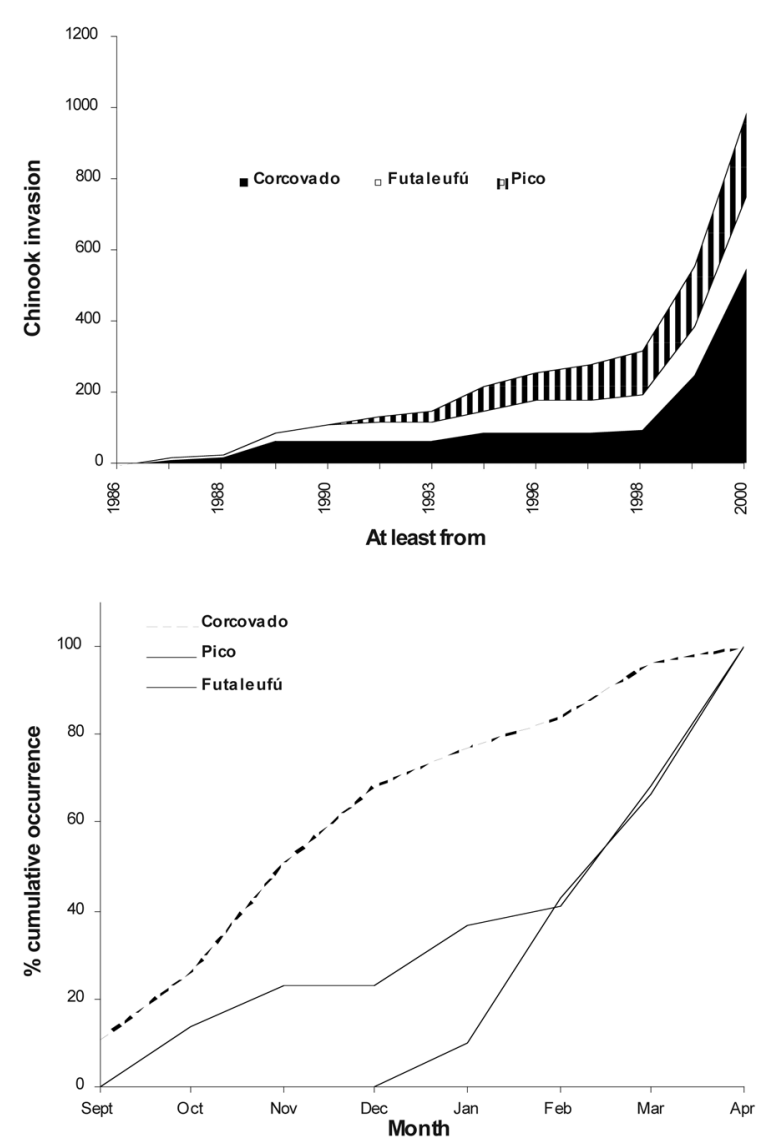

Fig. 4. a. Historical occurrence of Chinook salmon in each of the three rivers, expressed as the cumulative percent of reports by year of first sighting, based on the interviewers relate.

b. Seasonal occurrence of adult Chinook salmon in each of the three rivers, expressed as the cumulative percent of reports by month of first sighting, based on the interviewers relate.

river residency (ocean-type), and the other with a larger number of closely spaced circuli, which we identified with longer river residency (stream-type). The distribution of the number of circuli is clearly bimodal (Fig. $5 \mathrm{a}$ ), which is consistent with the existence of two alternative 

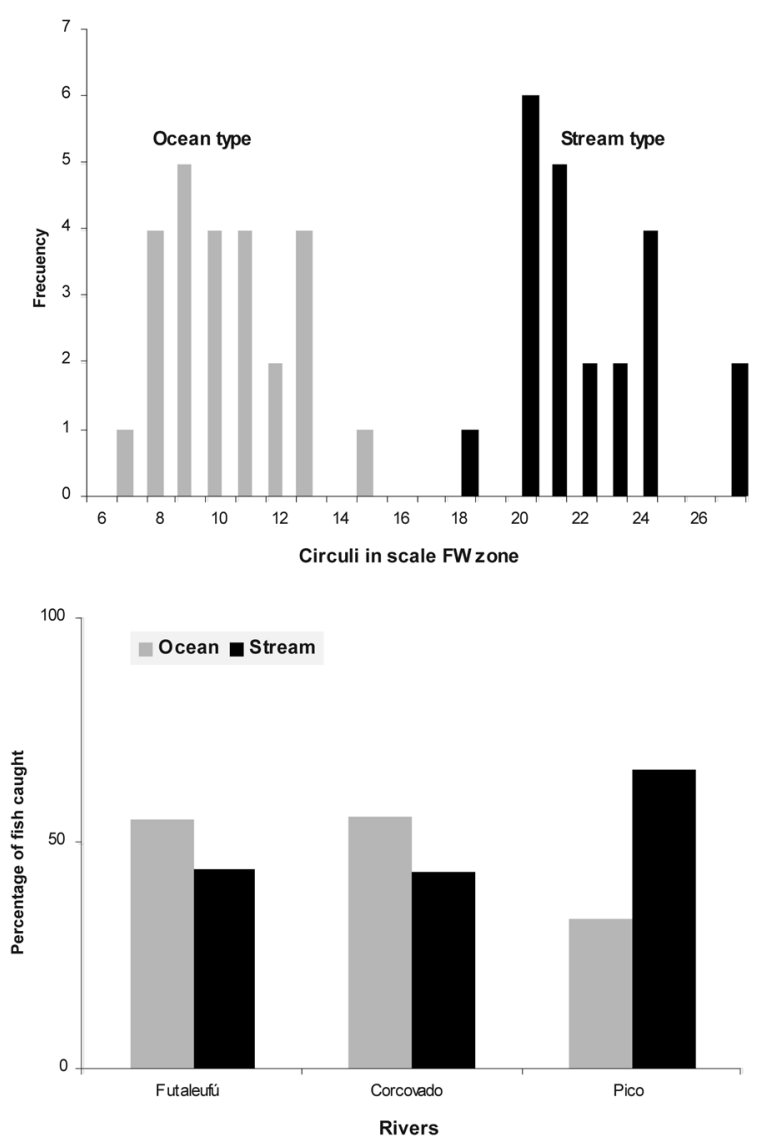

Fig. 5. Incidence of stream and ocean type chinook in Pacific Rivers of Chubut. Upper panel: distribution of number of circuli counted in freshwater nucleus in scales of all fish analyzed. Classification of fish of each in each of the three rivers by stream residency type, using a classification breakpoint of 16 circuli in the freshwater nucleus.

stream residence strategies. The average number of circuli for each type (ocean: average $=10.19$, stream: average $=21.57$ ) are comparable to those reported for Chinook salmon elsewhere (Unwin \& Lucas 1993; Ciancio et al. 2005). The assignment of individual fish to each of the two freshwater residency types based on scale freshwater nucleus indicates that Corcovado and Futaleufú rivers were dominated by ocean-type individuals while stream-type was more common in the Pico river (Fig. 5 b); both types coexist within each of the three rivers. Moreover, in Corcovado river, 2 year old individuals showed a dominance of ocean-type population, but as age increased, the proportion of ocean and stream-type varies with between sexes (Fig. 6).
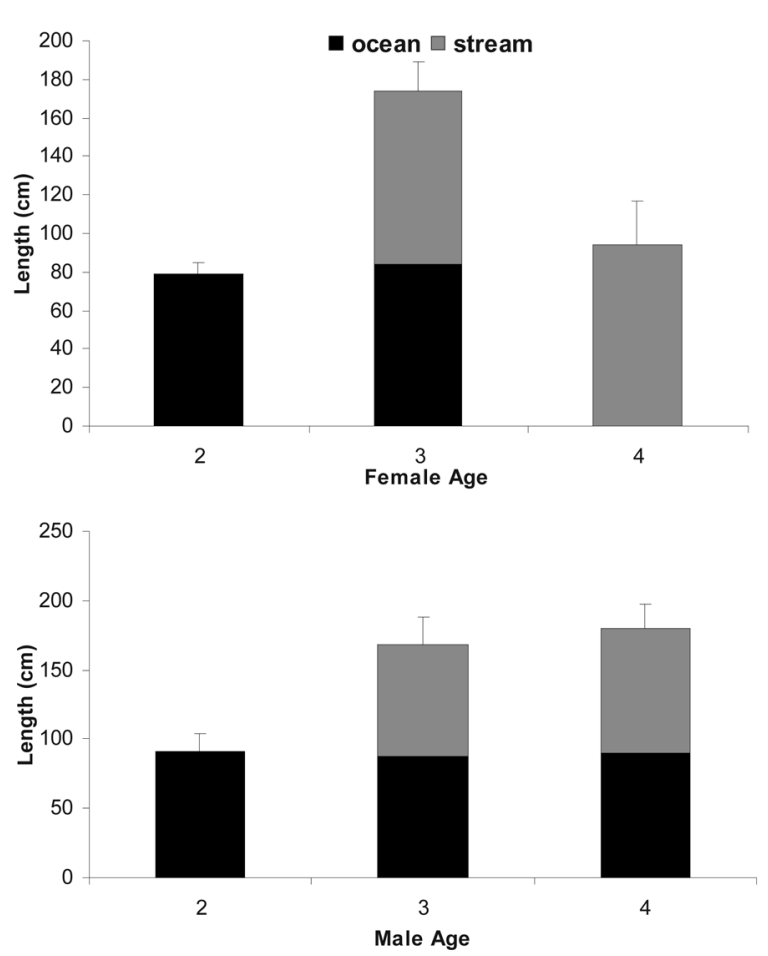

Fig. 6. Scale analysis showed two behavioral forms in the individuals of Chinook salmon life history in the three rivers studied. The percentages of ocean and stream type population were variable according to the gender and the age.

\section{Discussion}

Understanding the effects of biological invasions is one of the most difficult tasks in ecology. It requires understanding the factors that determine success of the invading species, as well as the ensuing effects on local communities. The analysis of the geographic arrangement of colonizing species can provide very useful information for the first issue, while setting the stage for studies on the second issue. The present distribution of Chinook salmon in Patagonia is very extensive (Soto et al. 2006, Becker et al. 2007, Correa \& Gross 2007), from $39^{\circ} \mathrm{S}$ on the Pacific, all the way south to the Strait of Magellan and to the Santa Cruz River on the Atlantic Ocean. The colonization of Patagonian rivers by Chinook salmon provides such an opportunity to explore invasion and ecological responses in real time. The regularity of the spawning runs in the Yelcho and Palena River Basins, together with the presence of Chinook fry in our study sites, clearly indicates that these rivers have established spawning populations of this species. Because multiple attempts were made to establish Oncorhynchus species through ocean ranching (Basulto 2003) 
and the frequency of accidental escapes from net pen aquaculture, it is not unlikely that this collection of populations has multiple origins. Future geographic analysis combining biological, behavioral and molecular data will help to establish the origin and connections between these populations, hopefully allowing the reconstruction of the point sources and the process of dispersion.

The three rivers analyzed were not homogeneous in terms of their use by Chinook salmon. While spawning was verified in all three rivers, only one, the Corcovado, seems to serve as a holding area for pre-spawning salmon early in spring. The headwaters of the Futaleufú and Pico rivers in Argentina serve primarily as spawning areas, and no pre-spawning areas were observed in those rivers. The simultaneous occurrence of Chinook salmon in the three rivers indicates that they may have been colonized as part of the same event. Moreover, the temporal correlation with the development of ocean ranching for this species in the Chiloé region suggests that the fish may well have originated in escapes from some of these enterprises. Chinook salmon comprise only a $0.65 \%$ of all the salmon production in this region, but no other species are known to have colonized these same reaches. Ciancio et al. (2005) and Pascual \& Ciancio (2007) have proposed that the plasticity in the life cycle of Chinook salmon may be responsible for its remarkable success as an invading species as compared to other anadromous species.

A new indication of the plasticity in the timing of life cycle events in Chinook salmon is provided by our finding of a combination of stream and ocean ecotypes in the three rivers in our study. Whereas Chinook populations in their native range are composed of either ocean or stream ecotypes (Healy 1991), mixed ecotypes appear to be the norm in exotic populations, since they were found in all populations described: several populations in New Zealand (Quinn \& Unwin 1993), one population in the Santa Cruz River Basin (Ciancio et al. 2005), and the populations in the three rivers of this study.

Freshwater residence often co-varies with the timing of the adult return to freshwater; populations that produce stream type juveniles tend to have adults returning earlier in the year than ocean type populations (Healy 1991). It is likely that run timing variations, which were found in New Zealand Chinook by Quinn \& Unwin (1993), exist in Patagonia Chinook as well. Our data indicates that early runs, comparable to a spring or summer Chinook in the Northern Hemisphere (Healy 1991), occur in at least one of the rivers, the Corcovado. The plasticity in run timing and freshwater residence should have served as a facilitator in the establishment of this species. An invading population of spawning fish, with an assortment of spawning migration schedules, should be more likely to match conditions in the receiving environments. Likewise, the viability of the descendants of those successful spawners would be enhanced by an assortment of river residence and ocean migration schedules.

\section{Conclusion}

In the present paper we reported the colonization of three rivers shared by Chile and Argentina by Chinook salmon. We relate the progress of the invasion in Argentinean rivers to the salmon production in southern Chile and describe some general biological characteristics of these populations. The regularity of spawning runs and the presence of spawning areas indicates that spawning populations are established in these three rivers. The historical and temporal correlation of the occurrences of this species with the development over last 20 years of ocean net pen production in Chile suggests that it may well have originated in escapes from these enterprises. The three rivers studied showed differences in their use by Chinook salmon. While spawning was verified in all three rivers, only one, the Corcovado, seems to serve as a holding area for pre-spawning salmon early in spring. The headwaters of the Futaleufú and Pico rivers in Argentina, on the other hand, serve primarily as spawning areas. A new indication of the plasticity in the timing of life cycle events in Chinook salmon is provided by our scale analysis which indicates that, like in New Zealand populations, it is a combination of stream and ocean ecotypes, co-varies with the timing of the adult return to freshwater and represents a colonization event by both spring and ocean ecotypes; whereas Chinook populations in their native range are composed by either ocean or stream ecotypes. It is clear by now that Chinook salmon have found a suitable habitat in river basins of Patagonia. The central question arises of what their effect could be on the receiving communities, both marine and riverine.

\section{Acknowledgements \\ We thank Dr. Trey Walker (High Seas Salmon Project, School of Fisheries, University of Washington, Seattle, USA) for help with scale interpretation, Dirección de Pesca Continental, Chubut, Argentina, for support to CYDP, sport anglers, local residents, fishing guides and fishing guards, for information and logistics. Finally, we wish to thank two anonymous referees for thoughtful reviews of the manuscript and for constructive suggestions for its improvement. This is the contribution to the Laboratorio de Investigaciones en Ecología y Sistemática Animal (LIESA) N ${ }^{\circ} 32$.}

\section{References}

Basulto S. 2003. El largo viaje de los salmones: una crónica olvidada, Propagación y cultivo de especies acuáticas en Chile. Maval Limitada Editores, Santiago, Chile, 102 p. 
Becker, L., Pascual, M.A. \& Basso, N. 2007. Colonization of the southern Patagonia ocean by exotic Chinook salmon. Conserv. Biol., 21:1347-1352.

Ciancio J.E., Pascual M.A., Lancelotti J., Rossi C. \& Botto F. 2005. Natural colonization and establishment of a Chinook salmon Oncorhynchus tshawytscha, population in the Santa Cruz River, an Atlantic basin of Patagonia. Environ. Biol. Fish., 74, 219-227.

Cooper A.B. \& Mangel M. 1999. The dangers of ignoring metapopulation structure for the conservation of salmonids. Fishery Bull., 97, 213-226.

Correa, C. \& Gross M.R. 2007. Chinook salmon invade southern South America. Biol. Invasions, DOI 10.1007/ s10530-007-9157-2.

Coronato F.R. \& Del Valle H.F. 1988. Caracterización hídrica de las cuencas hidrográficas de la provincia de ChubutCENPAT-CONICET. Puerto Madryn. Chubut. Argentina, 183 p.

FAO 2002. Fishstat Plus, V2.30. Universal softwate for fisheries statisctical time series, FAO Fisheries Department, Roma, Italy.

Grosman F. 1992. Algunos aspectos de la biología del "salmón del Pacífico" Oncorhynchus tshawytscha presente en la provincia del Chubut. Technical report. Centro de Ecología Aplicada del Neuquén and Japan International Cooperation Agency, Junín.

Healy M.C. 1991. Life History of Chinook Salmon (Oncorhynchus tshawytscha). Pages 313-393 in: Pacific Salmon Life Histories, Groot C. \& Margolis L. (eds). University of British Columbia Press, Vancouver, Canada.

Hilborn, R. \& Mangel, M. 1997. The Ecological Detective. Monographs in Population Biology. Princeton University Press, Princeton, USA

Koo T.S. \& Isarankura A. 1967. Objective studies of scales of Columbia River Chinook Salmon, Oncorhynchus tshawytscha (Walbaum). Fishery Bull., 66, 165-180.

Paruelo J.M., Beltrán A., Jobbagy E., Sala O. \& Golluscio R.A. 1998. The climate of Patagonia: general patterns and controls on biotic processes. Ecología Austral, 8, 85-101.

Pascual M.A. \& Ciancio J.E. 2007. Introduced anadromous salmonids in Patagonia: risks, uses, and a conservation paradox in: Ecological and Genetic Implications of Aquaculture Activities.
Bert T.M. (ed.). Springer, New York City, New York, USA. Chapter 18.

Pascual M., Macchi P., Urbanski J., Marcos F., Riva Rossi C., Novara M. \& Dell' Arciprete P. 2002. Evaluating potential effects of exotic freshwater fish from incomplete species presence-absence data. Biol. Invasions, 4, 101-113.

Quinn T.P. \& Unwin M.J. 1993. Variation in life history patternes among New Zealand Chinook salmon Oncorhynchus tshawytscha populations. Can. J. Fish. Aquat. Sc., 50, 1414-1421.

SalmonChile 2005. Asociación de la Industria del Salmón de Chile A.G. www.salmonchile.cl

SERNAP 2005. Anuario Estadistico de Pesca. Gráfica Nacional. Valparaiso, Chile.

Sistema Nacional de Información Hídrica-Subsecretaría de Recursos Hídricos de la Nación. www.hidrosargentina.gov.ar

Soto D., Arismedi I., Di Prinzio C. \& Jara F. 2007. Establishment of Chinook salmon (Oncorhynchus tshawytscha) in Pacific basins of Southern South America and its potential ecosystem implications. Revista Chilena de Historia Nat., 80, 81-98.

Soto D., Arismendi I., Gonzalez J., Guzman E., Sanzana J., Jara F., Jara C. \& Lara A. 2006. Southern Chile, trout and salmon country: conditions for invasion success and challenges for biodiversity conservation. Revista Chilena de Historia Nat., 79 , 97-117.

Soto D., Jara F. \& Moreno C. 2001. Escaped Salmon in the inner seas, Southern Chile: Facing Ecological and Social Conflicts. Ecol. Appl., 11, 1750-1762.

Sokal R. R. \& Rohlf F. J. 1995. Biometry. The Principles and Practice of Statistics in Biological Research. $3^{\text {rd }}$ Edition. Freeman W.H. \& Company: New York, 859 p.

Unwin M.J. \& Lucas D.H. 1993. Scales characteristics of wild and hatchery Chinook salmon (Oncorhynchus tshawytscha) in the Rakaia River, New Zealand, and their use in stock identification. Can. J. Fish. Aqua. Sci., 50, 2475-2484.

Veblen T.T., Donoso C., Kitzberger T. \& Rebertus A. 1996. Ecology of Southern Chilean and Argentinean Nothofagus Forest. 403 p, in: The Ecology and Biogeography of Nothofagus Forest, Veblen T.T., Hill R.S. \& Read J. (eds). Yale University press, London. 